\title{
FACT-CHECKING IN A CRUMBLING DEMOCRACY: Implementation of "Sem Migué" platform during local elections in São Luís
}

CHECAGEM DE FATOS NUMA DEMOCRACIA EM XEQUE: Implementação da Plataforma Sem Migué nas eleições municipais de São Luís

VERIFICACIÓN DE HECHOS EN UMA DEMOCRACIA EN JAQUE: Implementación de la plataforma "Sem

Migué" en las elecciones municipales de São Luís

\section{Jorge Araújo Martins Filho}

Mestrando em Comunicação. Aluno do Programa de Pós-graduação em Comunicação - Mestrado Profissional (PPGCOMPRO) da Universidade Federal do Maranhão.jfilho.araujo@gmail.com

\section{0-0001-5463-6950}

\section{Li-Chang Shuen}

Doutora em Ciências Sociais (UnB). Professora do Programa de Pós-graduação em Comunicação Mestrado Profissional (PPGCOMPRO) da Universidade Federal do Maranhão). li.chang@ufma.br

\section{0-0001-9192-6471}

Correspondência: Universidade Federal do Maranhão, Av. dos Portugueses, 1966 - Bacanga, CEP 65080-805, São Luís, Brasil.

Received: 02.16.2021.

Accepted: 04.16.2021.

Published: 07.01.2021.

\begin{abstract}
:
The aim of this research is to test the applicability of a collaborative and decentralized model of fact-checking during the 2020 elections in São Luís/MA. The model was materialized into a platform called "Sem Migué", in which volunteers had the opportunity to publish their own fact checks in the form of verification forums. The experiment seeks to investigate how this practice could help the participants deal with disinformation. The results will be used as resources in the development of an updated version of the model.
\end{abstract}

KEYWORDS Disinformation; Democracy; Journalism; Fact-checking.

\section{Introduction}

This article presents a report of the experiment made within the scope of local elections in São Luís in 2020 with the objective of testing the applicability of a collaborative and decentralized model of fact-checking from a platform entitled "Sem Migué". To make the project feasible we recruited 24 volunteers - among journalists and non-journalists - who received training about the adopted methodology and had access to the discussion forums where everyone could publish their verifications about the degree of accuracy of the speech of candidates for mayor. The research seeks to investigate in which way the experience with this model of checking could help the participants to deal with the disinformation phenomena. We developed a minimum viable product which was experienced during the electoral propaganda until the date of the second round of elections.

We considered the concept of disinformation adopted by Claire Wardle and Hossein Derakhshan (2017), who define it as the dissemination of fake news with the intention of causing damage. The phenomenon is commonly inserted within the context 
of abundance of data processing and transmitted by the digital technology and its decentralized flow of information and communication. This scenario is underlying to the legitimacy crisis of renowned institutions - journalism is one of them - in many liberal democracies to the extent that grow speeches and movements that have been being called by some authors of authoritarian populism or far right (NORRIS; INGLEHART, 2019; BENKLER; FARRIS; ROBERTS, 2018). These elements are part of the ongoing media ecosystem in which the news' production and broadcast are no longer exclusively controlled by the professional journalism outlets.

In this regard, the deceptive content widespread over the internet have been also called as fake news, term that we avoid using due to the confusion in concept that it may occur - after all, if an information is considered fake it should be not considered as news. Furthermore, the disorder of the information is something far more comprehensive that the sphere of news production implied when using the word news (HAIDEN; ALTHUIS, 2018). Other problem is within the character of novelty. Although the discourse in defense of the truth and the professional ideals we understand the traditional press as a political agent capable of deceive long before the arrival of digital networks. There are no news on that. The uniqueness of the phenomenon of disinformation is on the easiness extended to a greater range of groups and social actors to obtain political and/or economic gains through the spread of lying or distorted narratives.

Even that fact-checking agencies have recently multiplied and debunking rumors (MANTZARLIS, 2018), these initiatives linked to the professional journalism area are not able to verify the total of questionable content that circulates through the internet or even to guarantee that the correction have the same reach of the disinformation pieces. Many times fake information continue to be shared even after being contradicted by the agencies (REIS; MELO; GARIMELLA; BENEVENUTO, 2020).

This may occur because there are people who don't care if the information shared is fake or not for a variety of reasons, as long as it strengths their political agenda (MENDONÇA; FREITAS, 2019). But there are also people who are deceived by that ones who intentionally spread formulated or distorted content. In these situations, the practice of fact-checking can be useful, but agencies are used to operating in a business model based on lack of resources, whereas disinformation explores the logic of abundance and deconcentration in networks. Thus, we propose a collaborative and decentralized model of fact-checking - in order to disseminate the practice of checking as something that any citizen is capable to do as long as he has the access to the technological resources and knowledge of the tools available for that purpose. 
It is a research-action as the objective is not only to describe reality but also to make an intervention (GIL, 2008). The indicator used to evaluate the result of the experience are the performance of posts made at the platform Sem Migué, the questionnaires applied with the volunteers and the participating observation conducted along the work. Due to the Covid-19 pandemic, all meetings with the participants were on-line. Communication channels were Google Meet, Whatsapp and e-mails.

The next sections are organized according to the stages of the action plan referring to the experiment. The first part presents how we got to the materialization of our minimum viable product, Sem Migué platform. The second one describes how it happened in practice the test of this collaborative and decentralized fact-checking model, evidencing its potentialities and limitations. Lastly, on final considerations we summarized the main results and explained shortly how they can help us to update the model that can be reproduced in future experiences.

\section{Viabilization of a minimum viable product}

In the jargon of technological entrepreneurship, mvp or "minimum viable product" is the preliminary version of a product - completes the sufficient only to measure the impact and the value delivered to users (MOOGK, 2012). In this research we sought to enable a mvp that allowed to fulfill the purpose of testing the applicability of a collaborative and decentralized fact-checking model. Thus we initially defined which would be the essential characteristics of the artifact we would propose.

According to Santos (2018) an artifact can be classified in different categories according to its tangibility levels, that can go from the concept used to operate a solution to the product in operation inside the environment where the demand was originated. Among the more accepted types of artifacts are the constructs, models, methods and instanciation. The main artifact we propose is a model, in other words, the description of a system that combines constructors (or concepts) defined beforehand. Even so, to test the applicability of the model, it ws necessary to stablish a checking method and an instaciation, materialized on the minimum viable product we chose to call Sem Migué platform.

To define the essential characteristics of the model and subsidies the creation of a suitable checking method, we analyzed the methodology of two national fact-checking agencies: Lupa and Aos Fatos. There are the only two journalistic organizations undersigned at the International Fact-Checking Network (IFCN) currently operating in Brazil. The Code of Principles of IFCN has five points requested to its members: a) Non- 
partisanship and equity in checking; b) Transparency of sources used for verification; c) Transparency of the financing sources of the project; d) Transparency of the checking methodology; e) Commitment to a correction policy of the published work.

Besides these guidelines each one of the selected agencies follows their own verification procedures, which we sought to identify through visiting the presentation sections on the respective websites. Both adopt similar procedures of selecting agendas: information are chosen according to its relevance to the public interest, the profile of who delivered it and the size of repercussion of the content in media. Both Lupa and Aos Fatos exclude of the checking scope opinions and provisions of the future. Lupa adds that also does not check wide concepts - specifying the type of information they verify: historical documents, statistic data and comparisons or affirmation about legality or constitutionality of a fact.

Both means of communication adopt tags to classify the degree of veracity of information. Lupa uses "fake", "contradictory", "exaggerated", "underestimated", "unsustainable", "true, but", "true", "too early to tell" e "to keep track of". Aos Fatos' tags are: "fake", "contradictory", "exaggerated", "unsustainable", "distorted", "inaccurate" e "true". The use of these categories suggest an attempt to cover the informational complexity of declarations and rumors, recognizing and pointing where is the factuality of information supposedly untrue and where there are inaccuracies on sentences supposedly true.

One of the features of the methodology informed by Lupa is the almost exclusive phocus on the use of official sources - even when there is no accessible database, the reporters are directed to resort to the Access to Information Law (LAI) and to press offices. As complementary forms of verification, one can ask for a specialist analysis and go into the field with photographic, audio and/or video equipments. When it comes to the verification of speeches of politicians and public authorities the agency also asks for the official stance of who was checked.

The methodology described by Aos Fatos uses the expression "trusted source" to guide the checkers in their verifications. Official sources are queried according to the need and if they not considered enough, reporters should consult alternative sources.

Our project adopted elements of these two methodologies to elaborate a set of guidelines that could lead the participants of the first experiment with our model of factchecking. As agencies organize the work around a business structure - with a team of professionals with employment relationship and payment of wages -, it would be necessary to implement adaptations as our proposal is inspired in open communities with 
distributed dynamic. Chris Anderson (2012) defends this type of organization in opposition to traditional business models:

Web allow people to demonstrate what they can do, independently of schooling and background. It also allows the formation of groups of individuals who start to work together, easily, out of the context of company, and it does not matter if it is as "work" or "leisure". And these more informal organizations are much less subjected to geography restrictions. (ANDERSON, 2012, p. 175)

In this context, the journalist practice has expanded and it can be found in the framework of more traditional organizational structures as well as in less institutionalized emerging dynamics. In the mass media era, the newspapers, radio and television used to operate in the economic logic of lack of resources, so the journalistic production was enabled in industrial model that were centralized in the hand of the press outlet owners. With the reconfiguration of the media ecosystem, emerged the paradigm of abundance and post-industrial journalism, which multiplied the number of actors and organizations involved with the News production and affected the traditional ways of financing (CAPOANO, 2018).

Although the insertion of a greater multiplicity of actor in the production dynamics and informative content broadcast may seem at first the realization of a utopic media democratization, this phenomenon also brought to evidence a series of problems. In practice, what is observed in a very evident way is that the logic of abundance has been being used to foster a polarized environment much more reactive than reflexive, where arise new forms of production, sharing and news consumption much less attached to regulations or editorial policies (SANTAELLA, 2018).

This is then a fertile ground to the multiplication of disinformation campaigns that employ increasingly sophisticated techniques on the spread of lies. Yet there is no signal at the horizon of return to exclusivity paradigm of information flow from one to many and this is not the objective of this advocacy. The logic of abundance and decentralization should remain as main characteristic of networks. That is why we defend the development of solutions that aid the users of these networks to deal with disinformation agents, without the intention to eliminating the problem for good. It is in this sense that the collaborative and decentralized model of checking was conceived.

In order to systematize this artifact and elaborate an action plan we used Canvas as a base to business models proposed by Alexander Osterwalder and Yves Pigneur (2011) that has been serving to understand and redraw not only business and corporate initiatives but also non-profit organizations and even civil projects, such as this project. 
After some strategic adaptations we reached the following table. IN the sequence we summarize the choices for each one of the nine topics that compose this action plan.

Figure 1: Canvas Model of Sem Migué Project

\begin{tabular}{|c|c|c|c|c|c|}
\hline \multirow{2}{*}{$\begin{array}{l}\text { Main } \\
\text { Partnenships } \\
\text { - Volunteer checkers of } \\
\text { different profiles - not only } \\
\text { professionals or } \\
\text { Communication students, } \\
\text { but also actors of social } \\
\text { movements, neighborhood } \\
\text { associations, political } \\
\text { parties, etc.) } \\
\text { - UfMA (TT.l. workers, scholars } \\
\text { from Information Science } \\
\text { and Design) } \\
\text { - Agència Lupa (mentorship } \\
\text { during the corstruction of } \\
\text { the project and training the } \\
\text { collaborators) }\end{array}$} & $\begin{array}{l}\text { Key activities } \\
\text { - Recruiting and training } \\
\text { collaborators for the } \\
\text { application of fact-checking } \\
\text { methodology. } \\
\text { - To moderate/organize the } \\
\text { availability of verifiable facts. } \\
\text { - Verification and fact- } \\
\text { checkings. } \\
\text { - Content distribution in other } \\
\text { media. }\end{array}$ & \multirow{2}{*}{\multicolumn{2}{|c|}{$\begin{array}{l}\text { Value } \\
\text { Proposal } \\
\text { - "An Election Sem Migue" - } \\
\text { collaborative platform of } \\
\text { checkings during local } \\
\text { elections in São Luis in } 2020 . \\
\text { - Collaboration among } \\
\text { checkers can allow more } \\
\text { complete results. } \\
\text { - Audience participation } \\
\text { (evaluating posts through } \\
\text { likes and suggesting agendas } \\
\text { for verification). } \\
\text { - Contribution to } \\
\text { disinformation combat within } \\
\text { the local context. } \\
\text { - Free access. }\end{array}$}} & $\begin{array}{l}\text { Ralationship with } \\
\text { the audience } \\
\text { - Checkers: stimulation to co- } \\
\text { creation and strengthening } \\
\text { the community through } \\
\text { WhatsApp groups with } \\
\text { collaborators; } \\
\text { - Visiting citizens: self service } \\
\text { (arny person can access the } \\
\text { platform, like the posts and } \\
\text { suggest agendas). }\end{array}$ & \multirow{2}{*}{$\begin{array}{l}\text { Impacted } \\
\text { audience } \\
\text { - volunteer checkers; } \\
\text { - Citizens of São Luis; } \\
\text { - Candidates for mayor; } \\
\text { - Candidates for councilor. }\end{array}$} \\
\hline & $\begin{array}{l}\text { Rislos to face } \\
\text { - Unavailable information at } \\
\text { the transparency websites } \\
\text { or SIC; } \\
\text { - Low adhesion of } \\
\text { collaborators. } \\
\text { - Unavailability of UFMA's } \\
\text { partners. }\end{array}$ & & & $\begin{array}{l}\text { Channals } \\
\text { - Own website; } \\
\text { - Social Network platforms } \\
\text { (instagram, Twitter, } \\
\text { Facebook); } \\
\text { - WhatsApp Business for } \\
\text { the general public; } \\
\text { - WhatsApp group with } \\
\text { collaborators. }\end{array}$ & \\
\hline \multicolumn{3}{|c|}{$\begin{array}{l}\text { Cost } \\
\text { Structure } \\
\text { - Website development and host; } \\
\text { : Logo Design and Visual Identity; } \\
\text { - Social Network promotion. }\end{array}$} & \multicolumn{3}{|c|}{$\begin{array}{l}\text { Sustainability } \\
\text { Model } \\
\text { - Partnership with I.T technicians and Design students from UFMA } \\
\text { - Partnership with Agéncia Lupa } \\
\text { - Crowdfunding; } \\
\text { - Googie Adsense. }\end{array}$} \\
\hline
\end{tabular}

Source: Created by the authors.

\section{Impacted Audience}

On the original model this first component is denominated "customer segments". In order to adapt this element to the logic of our project, we adopted the classification "impacted audience". This modification occurred because we perceived the consumption relationships would not be prevailing and that other types of bonds would be formed among the actors involved in the process. Thus we reached the audience segments we intended to impact: volunteer checkers, local electors in general, candidates for the position of mayor and candidates to the position of city councilor. This segregation was made from the different types of bonds that could be created and that we will explain better on the following topics.

\section{Value Proposal}

Being the main constituent of Canvas, the value proposal consists not only of the offered products but also in all that qualify and differentiate them. Among these elements, the innovation factor is one that is more used to be remember when elaborating strategies to solve problems and achieve public adherence. In the case of 
Sem Migué platform the News is in adoption of a fact-checking dynamic characterized by distributed dynamics.

When opening the position of checker to anyone who wants to contribute with the process we aim to face the disinformation problem from a logic of abundance and not of scarcity. In other words, we seek inspiration in economies based on the gift culture built from the use value and sharing of goods and services - then on the dominant paradigm in the economy of the capitalist market, which adapts itself to the exchange value among the lack of resources (JEMIELNIAK; PRZEGALINSKA, 2020).

Although gift economies exist already for a long time and their characteristics could be assigned event to pre-historic clusters, we comprehend that the logic of abundance is also present on the emerging paradigm of business models that have been frequently being put inside categories as collaborative society, sharing economy, gig economy, trust economy, etc. (JEMIELNIAK; PRZEGALINSKA, 2020; FRENKEN; SCHOR, 2017; RAVANELLE, 2019; COSTA, 2018).

Information is one of the goods that better illustrate the logic of abundance. A informação é um dos bens que melhor ilustram a lógica da abundância. It is a produced, shared resource and consumed unprecedented. Considered that it is in this context that emerges the disinformation phenomenon we also seek to get distance of the scarcity logic when thinking about our platform. We did not charge for the checking service. The idea was to disseminate the fact-checking practice as something that anyone can do, as only the professional journalism initiatives do not have the capacity of tracking and check the total of disinformation pieces that appear in networks nor the guarantee that its reports reach all people affected by the deceptive content.

Because of that, the value proposal includes the recruitment and training of volunteers that can be professional journalists or not. At Sem Migué platform one fact can count on a multiplicity of checking posted by many authors and it is the audience responsibility to evaluate the results. In this sense we seek to promote an educational work for media not only among the project workers but also with the visiting audience of the platform. Our intention was to stimulate visitors to remake the way of each checking through the links made available by the volunteers. As stated in Canvas we also intended to instigate external participation making the function of likes available, but this feature was out of the minimum viable product.

\section{Channels}


Channels are the means of communication that we used to take the value proposal to the audience we would like to impact. In this sense, the main channel was the site of the platform itself, in which we published the checking forums, we described our methodology and made available a form to receive agenda suggestions. The site was hosted at the Federal University of Maranhão (Universidade Federal do Maranhão UFMA)'s website, thanks to a partnership with the Superintendence of Information Technology.

We also used accounts on Instagram, Twitter and Facebook - as these websites have an important role on the spread of information in a fast and easily scalable way. We also made available to the public a number of Whatsapp Businness with the objective of receiving agenda suggestions and send to the registered contacts the checking forums' links on the platform.

We gathered the volunteers in a private Whatsapp group aiming to notifying the publication of new forums, to facilitate information exchange and to strengthen the collaboration network. Besides that, we also exchanged e-mails and made the training meeting through Google Meet, as the experiment occurred during the Covid-19 pandemic and the videoconferences resources were widely recommended as a way to respect social distance advised the health authorities.

\section{Relationship with the audience}

This component of the table was also adapted, replacing the term "customer relationship" by "relationship with the audience". We planned two types of bonds: cocreation and self-service. The first is about the relationship with the team of project workers in the way of stimulating the volunteer participation. The second one was developed so the visitors could navigate throughout the platform autonomously. The "self-service" bond should not stop us to stablish a more direct contact with some of them as during the dissemination of the experiment we announced cannels to send critics and suggestions to improve the platform.

\section{Sustainability Model}

At the original framework this was entitled "Sources of revenue" referring to the value that the customer of a company is keen to pay to receive a certain product or service. As the project objectives to disseminate the fact-checking to as many people as possible, it was necessary to find manners of supporting the platform operation without leaving aside the gratuity of the service offered to visitors. As we did not have sources of 
income we sought to cover the operational costs primarily thought strategic partnerships.

UFMA's support was materialized through the Superintendence of Information Technology (STI) and the team cooperated with the creation of a platform inside the Research and Journalistic Practices Laboratory (LABJOR)'s website. We also had the partnership of the university's Social Design Laboratory (LABDES) which developed the logo and visual identity of Sem Migué platform.

Our Canvas predicted a partnership with Agência Lupa for training volunteers, but it was not possible to accomplish this support and because of that we developed our own checking workshop. Also, we could not enable the predicted partnership with researchers from the IT area. Crowdfunding campaigns and the activation of Google Adsense service that are on our framework were not executed either, as the associations sealed were enough to enable the minimum viable product.

\section{Risks to be confronted}

This component replaces the original section "Main Resources" because we believed that the description exercise of human, physical and intellectual resources was amply covered in other parts of our Canvas. Therefore, we preferred to use this section to make a risk mapping that could threat the success of our experiment. We identified as focal: the unavailability of checking sources, the low adhesion of collaborators in forums and the difficulty of stablish the planned partnerships on the sustainability model. Expected strategies for mitigation these risks included previous check to the available on-line and alternative forms of raising sources that were not necessary as we saw.

\section{Key Activities}

Sem Migué's most important activities also represent the four fundamental stages of the work: recruiting and training of checkers, selection and organization of checking forums, accomplishment of the fact-checking work itself and the results distribution through social network on-line. The first two as in charge of the platform moderator and the two last are shared among all participants.

\section{Main Partnerships}

At Sem Migué, partners represent an essential component, once the project's volunteers are vital to the materialization of the collaborative checking model. In this sense the opening of recruiting for actors of many social areas was strategic - not only 
from Journalism and Communication. Our intention was to make viable open spaces to create bond between these collaborators. Since our planning we conceived the checking model of Sem Migué platform as a communicational process in which it could cross - or even crash - interests and distinct motivations to use the platform and collaborate with the verification work. But everyone would be inserted in a community with the purpose of dealing with the disinformation problem. Other expected partnerships were the ones previously named - being materializes only the support of STI and LABDES from UFMA.

\section{Cost Strutcture}

Initially we anticipated costs with the development and hosting of the platform's website, creation of visual identity and logo and the possibility of promoting the content on social networks on-line. The last one was the only we did not materialize. As we specified on our sustainability model, the two first items were made available through partnerships.

\section{Defining fact-checking guidelines}

Nine items presented above illustrate the model we planned to test through the definition of a checking method and of the instantiation of a fact-checking platform. As we said on the beginning of this section, the method we adopted was an adaptation from the guidelines of the agencies Lupa and Aos Fatos. Evidently the specificities pertain to the collaboration and decentralization proposals of our project. We summarized our procedures in six topics: 1 ) selection, 2) verification forums, 3) checking sources, 4) tags, 5) autonomy of collaborators and 6) comments mediation.

As well as on the national checking outlets we prioritized during the agenda selection the information spoken in the speech of politics and public authorities, mas we also expected the possibility of checking rumors that were spreaded on social networks on-line. We did not check opinions or provisions. As the experiment would be made during the period of local elections, we sought only relevant subjects for the local elections in São Luís and excluded from this selection the candidates' promises. Information inserted on forums would have to be checkable in documents and in public and trustworthy database.

As to the verification forums the methodology of Sem Migué advocates that each forum corresponds to a unique informative unity - for example, a single sentence of the speech of a candidate or, in case of a rumor, only the key aspect is put in question. This requirement has the objective of making every participant of a forum to verify and 
evaluate the same data, allowing the reading public to compare and evaluate how different actors can check the same information.

The choice of checking sources must be guided by transparency. Collaborators were oriented to always include links of the material they used - in case they were not available on-lie it would be necessary to share prints, photos, audios and other types of registries, making it clear how the information was obtained. It was strictly forbidden the use of anonymous sources. Official sources should always be contacted but we decided that alternative sources could be used in case the officials were not sufficient or trustworthy. Checkers were oriented to used trustworthy and primary sources - for example, scientific studies or reports of organizations and people entitled to speak about a certain subject.

We defined five tags that should be assigned by the collaborators to each information at the beginning of the posting of the forums. Data could be classified as: true, decontextualized, overstated, not able to affirm it (when there is no available data to prove the veracity) or fake. Checkers had the autonomy to choose their tags and publish their own reports. Posts had always the identification of the authors and the platform made available a profile of all checkers - exposing institutional working bonds, party affiliation, community association or any other nature relevant to transparency.

Finally, the work guidelines of the project made it clear the moderation policies of postings made by the collaborators volunteering on the forums. Checking was not submitted to revision or previous approval, but the moderator would have the prerogative of excluding contributions that disclose personal data of third parties or that manifest any type of hate speech about gender, color, ethnicity, beliefs or sexual orientation. There was no need of removing any post.

Being defined the artifacts of the model and method we moved to the instantiation of the minimum viable product. In the process, even if we did not implement all features initially expected, the service we made available was sufficient to collect results that we presented on the next topic and that will serve to elaborate a review of Sem Migué model.

\section{Potential and limitations of the model}

The mvp test occurred from September 17th to November 20th, 2020. Sem Migué platform was launched together with the recruitment campaign of volunteers on social networks on-line. The Logo was developed based on the regional proposal of the project, using a cazumbá as a reference, enigmatic characters of Maranhão's popular culture. At the image, the nose was elongated making a reference to Pinocchio - the wooden toy 
of childhood literature whose nose would increase every time he told a lie. To the name of the project we added the signature "at elections" to make it clear that it is an edition devoted to the election period.

Picture 2: Sem Migué Project logo

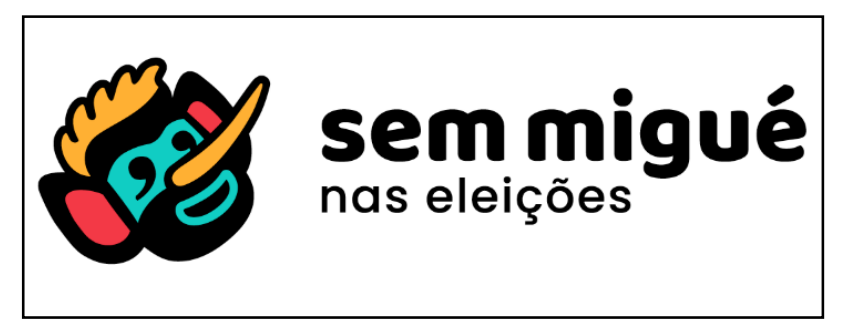

Source: < https://www.instagram.com/semmigueslz/>

We evaluated the experiment results from the analysis of the metrics from the content published at the platform, three questionnaires applied to the participant volunteers and the participative observation made along all action plan. During the first two weeks the plan consisted on promoting the platform on on-line social networks and trying to make an agenda at the local press. This period was also used to make a contact with the press offices of all mayoral candidates in São Luís to invite them to participate of the project. Once the idea was to make viable an open checking community without requiring non-partisan from volunteers, we assumed that there would be interesting to occupy this place. However, only one press advisor signed-up and refrained from participating.

Nevertheless, when we started to publish the checking forums at the platform, we stablished the routine of notifying the campaign teams every time their candidates had a speech checked, opening a space for them to explain themselves. Most of the times, press offices did not send any answer. Behind the scenes, some of them ignored us, as it was the case of the elected mayor Eduardo Braide's team (Podemos) and others complained about the negative checking about their advised clients. There was an episode of attempting of intimidation by the team of candidate Duarte Júnior (Republicanos), second place in election. After asking for an answer to the forum that verified if he had responded to a legal process for attacking an elderly person, we only received the copy of a court decision sentencing a local blogger for publishing an article about the subject. We kept the posting and the candidate did not take the case to Court.

The discomfort expressed by some press advisers and the behavior apparently disinterested of others could be partially because of the uniqueness of the initiative 
within the city of São Luís. The elections in 2020 were the first one in which local politicians had to deal with the checking of their speeches during debates, interviews and electoral propagandas. Besides Sem Migué, another fact-checking initiative aroused at the same time: "Rumbora Marocar". Suddenly campaigns had to deal with both projects unknown at that point and with the proposal of questioning their candidates. Distrustfulness is not a peculiar reaction for those who feel more comfortable dealing with a journalism prevailingly declaratory. Thus, the model has a potential to the developed in the sense of deriving political leaders of their comfort zone.

We checked speeches of all candidates - except Adriano Sarney (PV), who withdraw the election at the beginning of the campaign. During the period of electoral propaganda, we tried to check more sentences of candidates who were better positioned in voter preference polls. Thus, we registered 10 forums to verify affirmations of Eduardo Braide (Podemos), 6 of Duarte Júnior (Republicanos), 4 of Neto Evangelista (Democratas), 4 of Rubens Pereira Júnior (PCdoB), 4 of Bira do Pindaré (PSB), 3 of Silvio Antônio (PRTB), 2 of Jeisael Marx (Rede), 3 of Yglésio Moyses (PROS), 4 of Franklin Douglas (PSOL) and 2 of Hertz Dias (PSTU). We also checked a speech of candidate Carlos Madeira (Solidariedade) before his withdrawal from the electoral dispute. The mayor at that time, Edivaldo Holanda Jr. (PDT), and the governor of Maranhão Flávio Dino (PCdoB) also had sentences verified in a checking forum each.

All verification forums at the platform had the same structure, exemplified on Figure 3 below. In the title, there was always a question directing the aspect to the checked. Subsequently, a short introduction contextualized the agenda, previous to the headliner of the sentence that should be verified. The introductory text would also accompany a link to the original content - usually a video of interviews and debates published on YouTube. We used prints to illustrate where the information was extracted and we concluded this initial section with a short paragraph explaining the project. After that, there was the checking are in the form of forum.

Figure 3: Verification forum structure 

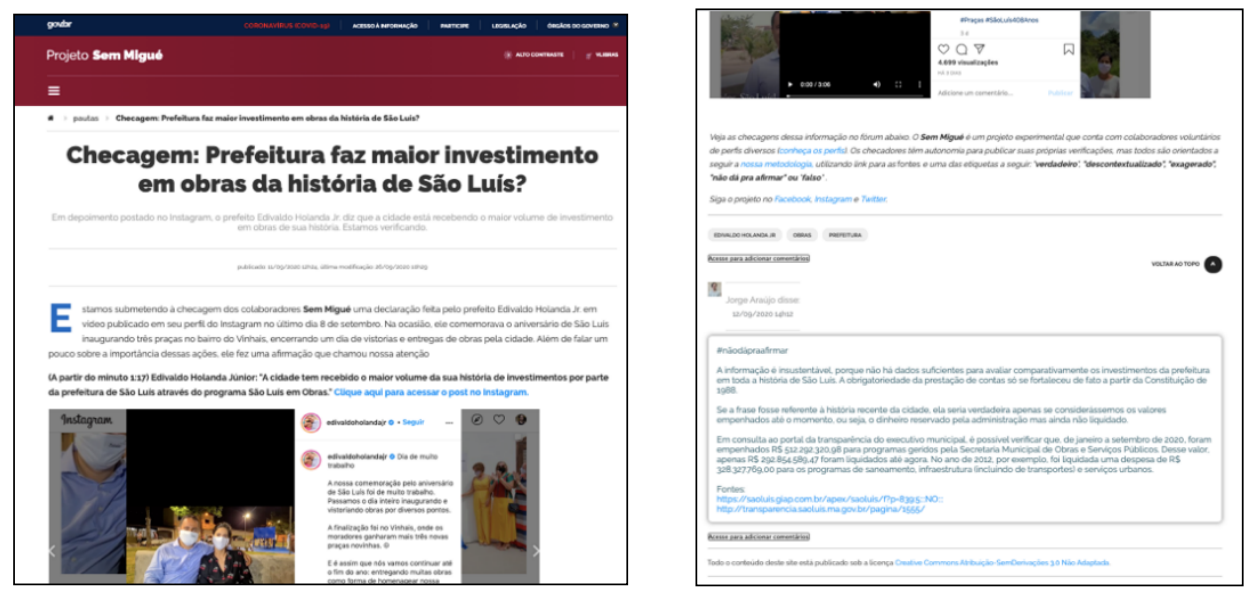

Source: < https://portalpadrao.ufma.br/labjor/sem-migue>

Until November 29 $9^{\text {th }}, 2020$, it was published 46 verification forums and 63 individual checkings. After the selection of agenda process, we avoided information that we had checked the veracity previously. Thus, we had 27 "fake" tags, 17 "decontextualized" tags, 9 "overstated" tags, 7 "not able to affirm it" tags and 3 "true" tags. According to data obtained through Google Analytics the platform had 6.502 views from October $16^{\text {th }}$ to November $30^{\text {th }}, 2020$. Most part of views in pages of the project's site came from research on Google (36\%), in direct links (22\%) - and only after that appeared Instagram (18\%), Twitter (16\%) and Facebook (6\%). Access peaks were on October 21st, one day after the debate made by the newspaper O Estado do Maranhão and Portal Imirante, and on November $28^{\text {th }}$, a day before the second round of elections - dates registered 370 and 343 views respectively.

Considering that, according to data from the Electoral Superior Court, the city of São Luís had 669.954 elector able to vote during 2020 elections, the reach of the platform was considerable small. We can give some possible reasons for that: lack of resources for content promotion, precariousness of the involvement gained among the main political leaders, short time to consolidate a network of regular readers, lack of influence of factchecking on voting definition. Despite of these limitations we could identify a great pedagogic potential on the model from the experience with volunteering participants.

Thirty-six people in total enrolled for the project but only the one that participated of the workshop or showed interest in watching the video of the training were kept. Thus, the experiment counted on 24 volunteers. We obtained the profile of the collaborators with the data given on the enrollment form. Almost all of them declared to have bachelor degree - $64 \%$ said they did or are taking a graduation and $33 \%$ had a post-graduation. Most given professions were student, professor and occupations linked to the 
Communication area (journalist, broadcaster, press advisor, social media and blogger). The group also had lawyers, public servants, an entrepreneur, a cultural producer, a person in the tourism career and a librarian.

During the enrollment the volunteers also informed the reason why they had interest on the project. Answers for that question are most around academic and civic interest. In general, the explanation showed a concern about the crisis in democratic institutions and a desire to contribute for more transparent and equilibrated elections. Knowing these motivations was important to map expectations as well as to identify common objectives that could be strengthen, facilitating the creation of bonds among members of the community that we would like to build. The declared motivations show a lot about the group's profile, mostly formed by people within the academic context and with a certain level of political awareness and, in some cases, of activism.

The second form filled by the experiment's participants had the objective of evaluate the checking workshop made on October $3^{\text {rd }}, 2020$ through Google Meet. The qualification lasted four hours and the content was shared in two parts. The first had the objective of explaining Sem Migué project, justifying our choice for a collaborative checking model and aligning the methodology adopted in the platform. On the second part, we showed tools and useful database for the verification work, interleaved these advises with practical exercises. Nineteen volunteers in total followed the training synchronously. The answers for the evaluation forms helped us to perceive which aspects were more useful and how we could improve the workshop. Among the positive aspects, the participants emphasized mainly the practical exercises and the advice of tools and database that could be used on checking. The critics suggested the improvement of time management. We received some considerations that the workshop could be shorter or divided in two days so the experience would be less exhaustive.

The third questionnaire was sent to the volunteers when we closed the experiment. From the 24 participants only 11 made at least one publishing at the platform. Nevertheless, as asked everyone to fill the final form - including the ones who did not actively participate of the process. One of the questions aimed to map the main reasons why they did not post their checkings. Almost all respondents mentioned lack of time. The second most mentioned impediment was unreliability or lack of knowledge. Two people reported personal problems and health problems related to the Covid-19 pandemic.

Although more than half of the participants did not publish their reports and that the great majority of the forums did not have more than one contribution, we considered 
that there was collaborative work. We asked this question to the most active checkers in the questionnaire and only one person alleged to have done the verification work alone. All other affirmed to have received contributions from the moderator and/or other colleagues from the checking community. Because of that, although the data of the table below shows that forums did not have much assortment of posted checkings we concluded that the collaboration happened in the platform's backstage.

Table 1: Number of fact checks by forums

\begin{tabular}{|c|c|c|c|c|}
\cline { 2 - 5 } & No checking & One checking & Two checkings & Three checkings \\
\hline Amount of Forums & 1 & 31 & 10 & 4 \\
\hline
\end{tabular}

Source: Created by the authors

Even in forums that had the greater numbers of checkings we perceived there was short variety in the use of tags. In almost all cases the verifications did not conflict. When we talked individually with some of the most active checkers in the forums, we detected they were less willing to post contributions when there was a checking in a forum. According to them, this happened because they did not have new data to enrich the discussion or because they were afraid of upsetting the colleagues that had already verified the information.

The final questionnaire also listed a series of affirmations and asked that volunteers checked if they would agree or totally or partially disagree. We highlight hereinafter some interesting results of this section. In general, the group tended to fully agree that the experience changed the perception of each one about the journalistic coverage during elections, that they acquired new competences and abilities and that the selection of the checking agenda was according to the proposed methodology. On the other hand, on an average, the volunteers agreed only partially that the experience had changed their perception about the political speech, that we load of workshops was enough, that the methodology proposed was enough to fulfill the checkings demands and that the work of Sem Migué had influence on the decision of his own vote or in other people's vote.

Other results of the experience could only be collected from the participating observation, that - because of the pandemic context - we adapted to digital environments were occurred all communication among the participants of the study. From video conversations or text messages we identified that some volunteers would 
not feel confident to post their checkings because they perceived that other colleagues from the community were more experienced or had more knowledge of the required database for verification. This perception reinforced the necessity of expanding pedagogical actions aiming to give more autonomy and confidence to collaborators.

Besides that, it was evident that the main difficulty faced by checkers that tried to verify information with official sources was the lack of data available at the Municipal Administration, the Municipal Chamber and the Legislative Assembly's website. When there was not reliable information on-line we would consult the press office of these institutions but in many occasions the work was prejudiced by the delay on transmitting information or even on the refusal on answering us. In a certain moment, a worker of the press office at the municipal executive power alleged the Institution would not get involved on the elections to justify the fact of not answering our information requests. Therefore, we confirmed that the lack of transparency of the local public power is a very limiting aspect to fact-checking.

Other highlight that is relevant to the experiment analysis is the absence of rumors at the sampling of information selected to the checking forums. That means all reports verified only the factuality of data delivered by the actors involved in the electoral process and that there was not the debunking practice - a type of checking that is much more indicative of that the disinformation phenomenon brings as new. Two information could be confirmed as rumors were verified with tags point that they were not all untrue. There were inserted at the forums "Has Duarte Jr responded to a legal process for attacking an elderly person?" and "Is Eduardo Braide investigated by the Federal Prosecutions Office?". Ironically both involved candidates classified these and other accusations as "fake news" in debates and electoral propagandas. This leads us to reinforce the idea that the term has been being wrongfully applied by politicians as a rhetoric weapon every time the disclosure of a data or report displeases them.

\section{Final considerations}

Impressions and data obtained from the first experience of application of our collaborative and decentralized model of fact-checking evidenced there are great challenges concerning popular mobilization in the combat against disinformation, as well as in the construction of a transparency culture mainly in the local public government entities. However, the difficulties we identified do not reduce the importance nor the necessity of initiatives that help to democratize the public debate and expand the possibilities of social control in public entities and agents. Therefore, it 
is valid the use of research results to update the model and testing new versions of its resulting artifacts.

For future applications we evaluated as essential to give more attention the pedagogical character of this work. This was clear enough on the evaluation of many participants of Sem Migué platform. Even the one who did not contribute actively on the checking forums could perceive how the fact-checking practice requires time, knowledge and resources to be executed - because of that, maybe the journalistic work could be more appreciated, whether performance in more or less institutionalized contexts. Besides that, they related a change on the way of perceiving the news coverage of the elections, which can suggest a more critical reception of the content they receive.

Other possible change concerns the implementation of more autonomy to the checkers on defining tags and agenda selection. In this first experiment, the choice of information to be checked was concentrated with the moderator but we consider that would be interesting to experiment a distributed dynamic since the beginning of the process. This change would bring closer the proposal of collaborative checking in the model of open communities - in which the risks are usually compensated by the gain in learning and potential to innovation.

\section{References}

ANDERSON, Chris. Makers: a nova revolução industrial. Tradução: Afonso Celso da Cunha Serra. Rio de Janeiro: Elsevier, 2012.

BENKLER, Yochai; FARIS, Robert; ROBERTS, Hal. Network Propaganda: manipulation, disinformation and radicalization in American politics. Oxford: Oxford University Press, 2018.

CAPOANO, Edson et al. Como se banca o jornalismo: Modelos, tendências e reflexões sobre financiamento de mídia. São Paulo:[sn], 2018.

COSTA, Ramon Bezerra. Economia da confiança: comunicação, tecnologia e vinculação social. Curitiba: Appris, 2018.

FRENKEN, Koen; SCHOR, Juliet. Putting the sharing economy into perspective. Environmental Innovation and Societal Transitions, volume 23, pp. 3-10, 2017.

GIL, Antônio Carlos. Como elaborar projetos de pesquisa. 4ed. São Paulo: Atlas, 2008.

HAIDEN, Leonie; ALTHUIS, Jente. The Definitional Challenges of Fake News. In: International Conference on Social Computing, Behavior-Cultural Modeling, and Prediction and Behavior Representation in Modeling and Simulation, Washington, 2018.

JEMIELNIAK, Dariusz; PRZEGALINSKA, Aleksandra. Collaborative Society. Cambridge, MA: The MIT Press, 2020.

MANTZARLIS, Alexios. Fact-checking 101. In: Journalism, 'Fake News' \& Disinformation: Handbook for Journalism Education and Training. Paris: UNESCO, 2018.

MENDONÇA, Ricardo Fabrino; FREITAS, Viviane Gonçalves. Fake News e o repertório contemporâneo de ação política. In: Encontro da COMPOLÍTICA, v.8, Brasília, 2019. 
MOOGK, Dobrila Rancic. Minimum viable product and the importance of experimentation in technology startups. Technology Innovation Management Review, v. 2, n. 3, 2012.

NORRIS, Pippa; INGLEHART, Ronald. Cultural backlash: Trump, Brexit, and authoritarian populism. Cambridge University Press, 2019.

OSTERWALDER, Alexander; PIGNEUR, Yves. Business model generation: inovação em modelos de negócios. Alta Books Editora, 2011.

RAVENELLE, Alexandrea J. Hustle and Gig: struggling and surviving in the sharing economy. Oakland, California: University of California Press, 2019.

REIS, Julio C.S.; MELO, Philipe; GARIMELLA, Kiran; BENEVENUTO, Fabrício. Can WhatsApp benefit from debunked fact-checked stories to reduce misinformation? Harvard Kennedy School Misinformation Review, 2020.

SANTAELLA, Lúcia. A Pós verdade é verdadeira ou falsa? Barueri: Estação das Letras e Cores, 2018.

WARDLE, Claire; DERAKHSHAN, Hossein. Information disorder: Toward an interdisciplinary framework for research and policy making. Council of Europe report, v. 27, 2017.

\begin{abstract}
RESUMO:
O objetivo desta pesquisa é testar a aplicabilidade de um modelo de factchecking colaborativo e descentralizado no âmbito das eleições municipais de São Luís/MA em 2020. Esse modelo foi materializado em uma plataforma intitulada "Sem Migué", na qual checadores voluntários tiveram a oportunidade de publicar suas próprias reportagens em fóruns de verificação. $O$ experimento busca investigar de que forma essa prática é capaz de ajudar os participantes a lidar com o fenômeno da desinformação. Os resultados vão subsidiar a elaboração de uma versão atualizada do modelo.
\end{abstract}

PALAVRAS-CHAVE: Desinformação; Democracia; Jornalismo; Fact-checking. 


\section{RESUMEN:}

El objetivo de esta investigación es poner a prueba la aplicabilidad de un modelo colaborativo y descentralizado de verificación de hechos (fact-checking) en el transcurso de las elecciones municipales del 2020 en São Luís, Brasil. Este modelo se materializó a través de una plataforma llamada "Sem Migué", en la que voluntarios tuvieron la oportunidad de publicar sus verificaciones de hechos en foros virtuales. El experimento pretende investigar como esta práctica puede apoyar a los usuarios a hacer frente al fenómeno de la desinformación. Los resultados subsidiarán el desarrollo de una versión actualizada del modelo.

PALABRAS-CLAVES:

Desinformación; Democracia; Periodismo; Fact-checking. 